\title{
THE PATHOLOGIC PHYSIOLOGY OF PELLAGRA
}

\author{
III. The Serum Calcium and Phosphorus, with Especial Refer- \\ ence to Nervous Symptoms \\ BY ROY H. TURNER \\ With the Technical Assistance of VIRGINIA BLANCHARD \\ (From the Department of Medicine, Tulane University of Louisiana School of Medicine \\ and the Medical Services of the Charity Hospital, Nerw Orleans)
}

(Received for publication October 27, 1930)

Interest in the calcium and phosphorus metabolism of pellagra was. based chiefly upon the clinical observation that sunshine is injurious to the pellagrin. This caused the disease to be compared with rickets, which is prevented or cured by sunshine. The two diseases afford a number of interesting contrasts. Rickets is a disease of the period of most rapid growth, particularly during infancy, early childhood and adolescence; while these are the age periods showing the lowest incidence of pellagra (1). Rickets develops in the winter and early spring and disappears during the summer, while pellagra appears in the late spring and summer and practically disappears in winter. Rickets is a disease of cities, and pellagra of the rural districts. Childbearing and lactation seem to be predisposing causes for both pellagra and osteomalacia, which may be considered a form of rickets. As far as injurious effect of light is concerned the relation to pellagra seems to be chiefly with lactation rather than pregnancy. Siler, Garrison, and MacNeal (2) brought out statistical evidence to show that, in pellagra, the period of gestation is a period of resistance to pellagra, as far as the manifestation of erythema is concerned. They also showed that the first three months after childbirth might be a time of great susceptibility to the erythema of pellagra for the mother, particularly if delivery occurred during the first eight months of the year. If childbirth occurred during the last four months of the year, the mother was particularly resistant to pellagra for the next four months. In- 
stead of gestation being a period of lessened susceptibility to osteomalacia it is a period of great danger (3).

Denton (4) found histological evidence of beginning arteriosclerosis in young pellagrins. Many workers (5) have shown that an excess of vitamin $\mathrm{D}$ in the form of irradiated ergosterol promoted arteriosclerotic processes. The dietary, which is supposed to cause pellagra in the Southern United States, is rich in unirradiated ergosterol taken with pork fat or cotton seed oil. The evidence just cited suggested that with the coming of the spring sunshine the ergosterol in the individual's skin might be activated in sufficient quantity to provide an excess of vitamin D. From another viewpoint the physiology of calcium might be of interest in pellagra. Much has been written about the influence of calcium on permeability of cell membranes. It is likely that the skin lesions of pellagra involve increased permeability of capillaries. While determinations of serum calcium and inorganic phosphorus may detect only the more gross abnormalities of metabolism, they may be of great value, particularly for orientation.

Ballif and Gherscovici (6) report that they determined the serum calcium by the method of Ward for 10 patients with severe pellagra, and that they constantly found values above the normal 10.5 to 13.5 mgm. per 100 cubic centimeters. They comment upon the unexpected occurrence of "hypercalcemia" combined with exaggerated reflexes.

\section{METHODS AND MATERIAL}

Venous blood was collected, without stasis, after a night's fast and allowed to clot under oil. Calcium was determined by Clark and Collip's modification (7) of the Kramer and Tisdall method. A fine capillary tip was fitted to the micro burette which delivered small drops of permanganate solution. Inorganic phosphate was determined by Gunther and Greenberg's (8) modification of the method of Fiske and Subbarow. Parallel determinations by the method of Fiske and Subbarow and by Greenberg's modification gave excellent agreement. The methods for determining serum albumin and globulin have been presented in a preceding article (9).

The patients studied for this report consist of 42 pellagrins, described in tabular form in article I of the present series (10), 6 additional patients with typical pellagra too incompletely studied to include in the 
TABLE 1

Data for patients other than the 42 pellagrins described in Article $I$ of the present series of papers

\begin{tabular}{|c|c|c|c|c|c|c|c|}
\hline 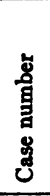 & 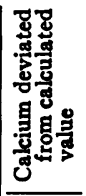 & 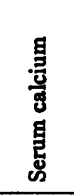 & 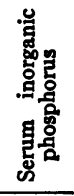 & $\begin{array}{l}\text { 員 } \\
\text { 吾 }\end{array}$ & 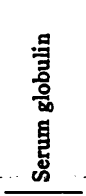 & 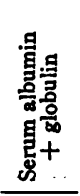 & Diagnosis \\
\hline & per cent & $\begin{array}{l}\underset{\text { merm. }}{\text { per }} \mathbf{1 0 0} \\
\text { cc. }\end{array}$ & $\begin{array}{l}\underset{\text { perm. }}{\operatorname{mgm}} \\
\text { cc. }\end{array}$ & $\begin{array}{l}\text { gms. per } \\
100 \text { cc. }\end{array}$ & $\begin{array}{ll}g m s . \\
100 \\
\text { cer. }\end{array}$ & $\begin{array}{ll}\text { sms. per } \\
100 \\
\text { cc. }\end{array}$ & \\
\hline 43 & +12 & 11.8 & 4.7 & 7.05 & 1.39 & 8.44 & $\begin{array}{l}\text { Early pellagra-vomiting and diar- } \\
\text { rhea. Dehydration. Died }\end{array}$ \\
\hline 44 & +16 & 10.7 & 4.4 & 3.64 & 2.42 & 6.06 & $\begin{array}{l}\text { Moderately severe pellagra; skin le- } \\
\text { sions } 1 \text { month }\end{array}$ \\
\hline 45 & +15 & 11.7 & 3.4 & 5.03 & 2.09 & 7.12 & $\begin{array}{l}\text { Convalescent pellagra; serum albu- } \\
\text { min previously very low }\end{array}$ \\
\hline 46 & +42 & 10.7 & 13.3 & 4.13 & 2.94 & 7.07 & Severe pellagra; skin necrosis, vomit- \\
\hline 40 & +33 & 10.1 & 11.6 & 3.88 & 2.50 & 6.38 & ing, diarrhea, dehydration, died \\
\hline 47 & -5 & 8.8 & 3.5 & 3.42 & 2.34 & 5.76 & $\begin{array}{l}\text { Early pellagra. Carcinoma of cer- } \\
\text { vix, with metastasis; radium ther- } \\
\text { apy; died }\end{array}$ \\
\hline 48 & +15 & 10.3 & 4.3 & 3.86 & 1.67 & 5.53 & Convalescent pellagra having shown \\
\hline to & +11 & 10.1 & 4.5 & 4.11 & 1.76 & 5.87 & $\begin{array}{l}\text { great clinical improvement before } \\
\text { study }\end{array}$ \\
\hline
\end{tabular}

Pellagra-like conditions

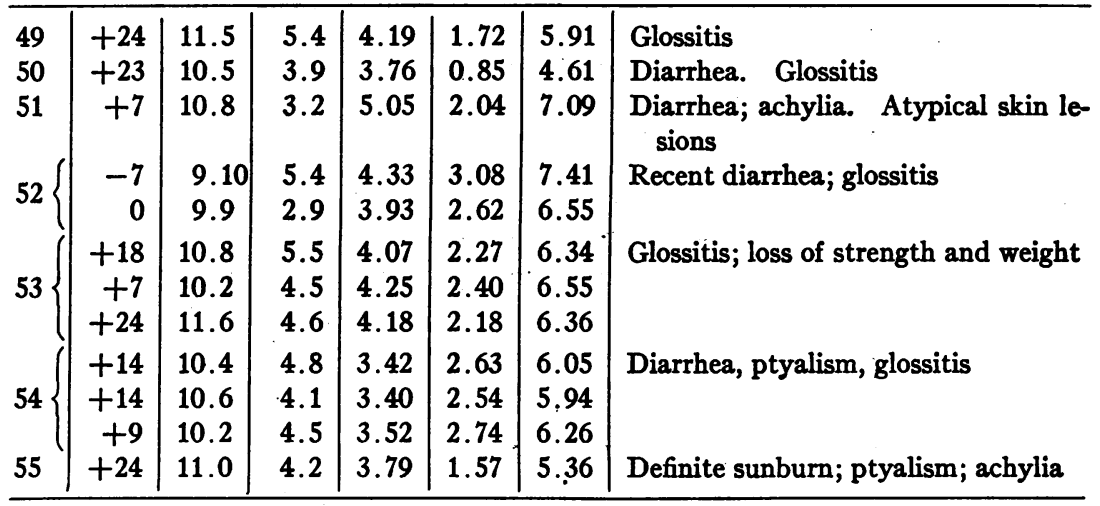

Definite bone disease

\begin{tabular}{l|r|l|l|l|l|l|l}
\hline 56 & +41 & 13.2 & 3.4 & 2.74 & 3.82 & 6.56 & Multiple myeloma \\
& +10 & 11.2 & 3.2 & 4.53 & 2.60 & 7.13 & Luetic periostitis \\
& +18 & 10.5 & 4.1 & 4.27 & 1.19 & 5.46 & \\
58 & +12 & 10.4 & 4.5 & 3.22 & 2.96 & 6.18 & Luetic periostitis \\
\hline
\end{tabular}




\begin{tabular}{|c|c|c|c|c|c|c|c|}
\hline \multicolumn{8}{|c|}{ TABLE 1-Concluded } \\
\hline 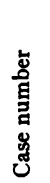 & 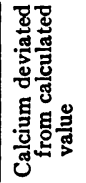 & 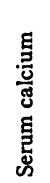 & 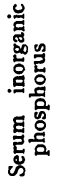 & 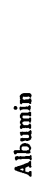 & 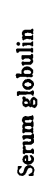 & 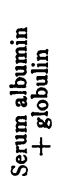 & Diagnosis \\
\hline
\end{tabular}

Patients with various diseases

\begin{tabular}{|c|c|c|c|c|c|c|c|}
\hline & per cent & $\begin{array}{l}\text { mgm. } \\
\text { per } 100 \\
\text { cc. }\end{array}$ & $\begin{array}{c}\text { mgm. } \\
\text { per } 100 \\
c c .\end{array}$ & $\begin{array}{l}\text { gms. pe } \\
100 \text { cc. }\end{array}$ & $\begin{array}{l}\text { gms. per } \\
100 \text { ce. }\end{array}$ & $\begin{array}{l}\text { gms. per } \\
100 \mathrm{cc.}\end{array}$ & \\
\hline 59 & -29 & 7.9 & 3.3 & 7.65 & 1.30 & 8.95 & Luetic heart disease; edema \\
\hline 60 & +13 & 10.0 & 5.1 & 3.84 & 1.88 & 5.72 & Arsenical dermatitis \\
\hline 61 & +10 & 10.0 & 5 & 3.52 & 2.48 & 6.00 & Arteriosclerotic heart disease; edema \\
\hline 60 & +11 & 9.6 & 4.8 & 4.43 & 0.77 & 5.20 & Pernicious anemia \\
\hline 02 & +9 & 10.3 & 4.3 & 5.03 & 1.28 & 6.31 & \\
\hline 63 & +2 & 8.8 & 4.5 & 3.73 & 1.21 & 4.94 & Pernicious anemia \\
\hline 64 & +12 & 10.2 & 3.8 & 3.58 & 2.03 & 5.61 & Luetic and hypertensive heart disease \\
\hline 65 & +6 & 9.9 & 3.9 & 3.52 & 2.50 & 6.02 & Gastrogenous diarrhea \\
\hline 66 & +8 & 10.3 & 3.4 & 5.05 & 1.18 & 6.23 & Healthy middle aged adult \\
\hline 67 & -4 & 9.7 & 4.1 & 4.76 & 2.71 & 7.47 & Menopause \\
\hline 68 & -11 & 8.6 & 3.2 & 3.85 & 2.42 & 6.27 & Pulmonary tuberculosis. Syphilis \\
\hline 69 & +8 & 10.9 & 4.6 & 5.31 & 2.32 & 7.63 & Obesity. Pyelitis \\
\hline 70 & -2 & 10.2 & 5.3 & 4.52 & 4.01 & 8.53 & Salpingitis. Pulmonary tuberculosis \\
\hline 71 & 0 & 10.0 & 4.7 & 5.07 & 2.55 & 7.62 & Neuritic beriberi \\
\hline 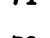 & -13 & 10.6 & 3.8 & 4.02 & 2.03 & 6.05 & \\
\hline 72 & -6 & 9.8 & 4.6 & 4.43 & 3.68 & 8.11 & Salpingitis \\
\hline 73 & -3 & 9.3 & 3.8 & 3.80 & 2.71 & 6.51 & Hypertensive heart disease \\
\hline \multirow[t]{2}{*}{74} & +11 & 10.8 & 4.7 & 3.50 & 1.46 & 4.96 & Early gastric cancer \\
\hline & +14 & 10.3 & 3.7 & 3.80 & 1.59 & 5.39 & Bacillary dysentery \\
\hline \multirow[t]{2}{*}{75} & +15 & 9.2 & 4.4 & 3.76 & 1.52 & 5.28 & \\
\hline & 0 & 10.3 & 4.4 & 4.28 & 3.68 & 7.96 & \\
\hline 76 & +6 & 9.8 & 3.4 & 3.60 & 1.98 & 5.58 & Amebic dysentery \\
\hline 77 & +5 & 9.3 & 3.9 & 3.37 & 1.84 & 5.21 & Bacillary dysentery \\
\hline 78 & +6 & 9.7 & 3.1 & 3.03 & 2.24 & 5.27 & \\
\hline 79 & +4 & 9.5 & 2.9 & 3.60 & 1.59 & 5.19 & $\begin{array}{l}\text { Hemiplegia, fecal incontinence, mild } \\
\text { chronic diarrhea }\end{array}$ \\
\hline 80 & +12 & 10.8 & 4.5 & 4.42 & 1.40 & 5.82 & Diarrhea, chronic \\
\hline 81 & +22 & 10.6 & 3.1 & 2.85 & 3.44 & 6.29 & Pernicious anemia \\
\hline 82 & +2 & 9.2 & 2.9 & 2.10 & 2.82 & 4.92 & Bacillary dysentery \\
\hline & +2 & 9.1 & 2.9 & 2.26 & 2.41 & & \\
\hline
\end{tabular}

general study, 7 patients suffering with disorders clinically like pellagra but without typical skin lesions, 3 patients with known disease of bones and 24 patients clinically without pellagra but suffering from a wide variety of diseases and without clinical evidences of disturbed 
calcium metabolism. In all, 181 simultaneous determinations of serum calcium, inorganic phosphorus, albumin and globulin were made on 82 individuals. The figures for individual determinations for 42 of the pellagrins are recorded elsewhere (10) and for all other patients in table 1.

Peters and Eiserson (11) derived a formula for determining expected serum calcium concentration which applies to the serum of individuals with normal calcium metabolism when total serum proteins (albumin and globulin) and inorganic phosphorus are known. Their formula is $\mathrm{Ca}=$ $0.255 \mathrm{P}+0.556$ protein +7 , when calcium and phosphorus are expressed in milligrams per $100 \mathrm{cc}$. and protein as grams per $100 \mathrm{cc}$. The mode of presentation of our data is based on their formula. Throughout this paper attention will be directed toward abnormalities in serum calcium levels, although it is realized that the phosphorus level may be equally or even more at fault. It may be noted, however, from the absolute values given in the tables that usually it is calcium and not phosphorus which deviates most from the usual mean values.

In figure 1 the results of the determinations of serum calcium for each patient are shown as per cent deviation from the calculated value, using the formula of Peters and Eiserson. By inspection of this graph it will be noted that there was a tendency, in the group of pellagrins, for serum calcium levels to be considerably higher than the calculated values; while the determined serum calcium content for patients without pellagra and without obvious bone disease approximated very nearly the calculated figures. One patient (case 56) suffering from extensive bone absorption due to multiple myeloma showed a serum calcium content 42 per cent above the calculated level, while 2 patients with luetic periostitis showed only slight increases.

More striking than the contrast between serum calcium levels of the patients with and without pellagra is the contrast between the serum calcium levels of individual pellagrins and groups of pellagrins. It will be noted that certain patients with pellagra showed persistently high serum calcium; others were persistently near expected, or normal levels, while considerable fluctuations are noted for others. When the patients are grouped according to the degree of deviation from the calculated calcium level, certain clinical features are found to be of interest. 


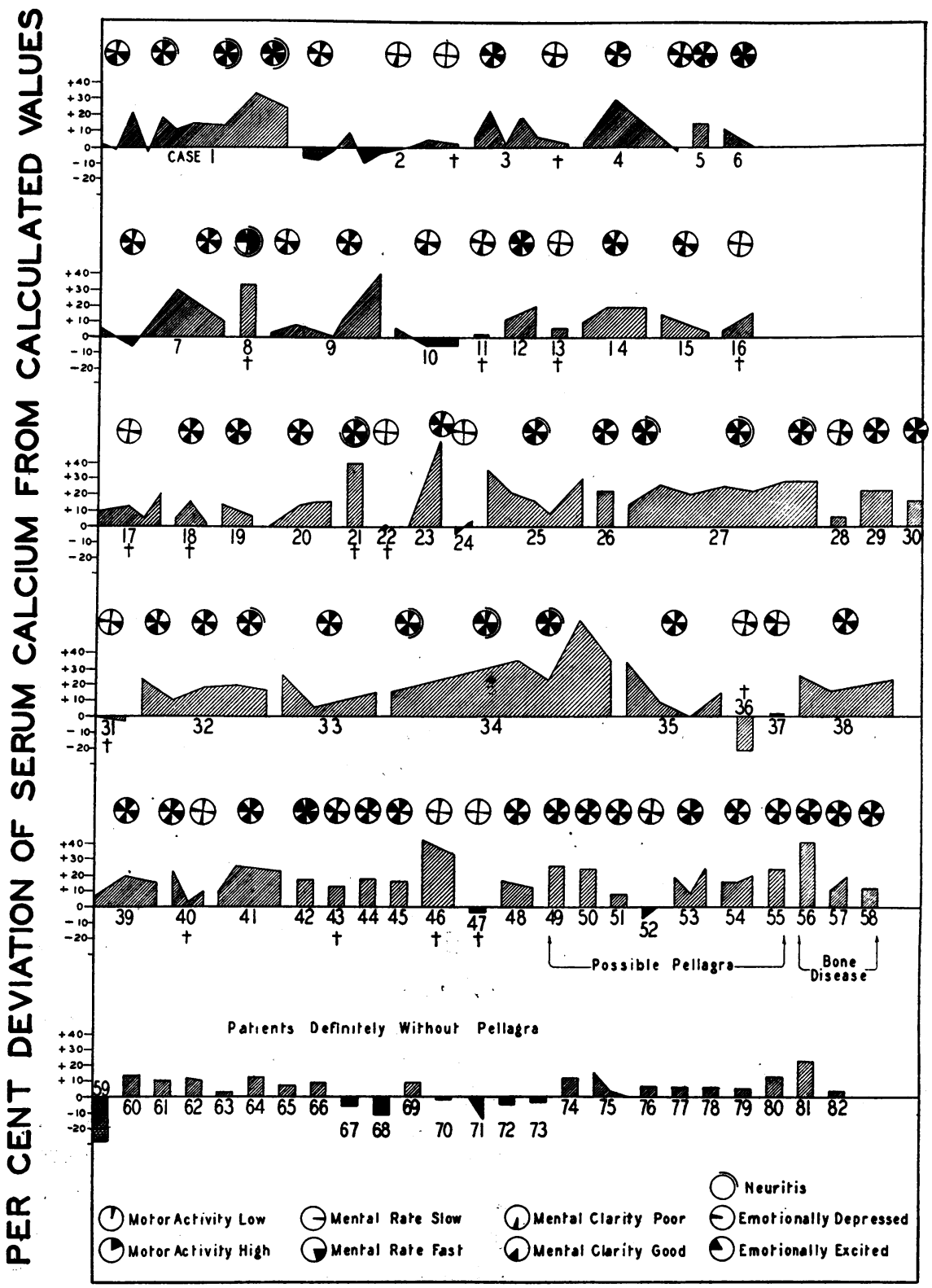

FIG. 1 
The patients who died in the hospital, indicated by crosses in figure 1 , for the most part showed little deviation of their serum calcium from calculated values. This is true of two other patients (cases 10 and 24), whose clinical condition at the time of discharge was such as to make death very likely within a week or two. However, there are striking exceptions. Three patients (cases 8, 21, 46) whose serum calcium concentrations were abnormally high died. Two of these patients (cases 8, 21) are of interest because of the unusual nervous manifestations which will be discussed later. The other (case 46) showed very high serum phosphorus concentration, probably due to oliguria. The patient suffered from both vomiting and diarrhea.

The mental status of pellagrins is of great importance, and should be an inviting field for psychiatric investigation. The so-called dementia has been much stressed in clinical teaching. It is an unfortunate term. The psychoses occurring in pellagra form several entities and not a single one. They include delirium, stupor, coma and the manic-depressive psychoses. In addition to the outspoken major psychoses, many pellagrins show depression without psychosis, apathy, a tendency to excessive sleep or insomnia and frequently extreme neurasthenia. In reviewing the psychic states of the pellagrins of our group we have been struck by a rough relationship between serum calcium levels and mental patterns. This relationship is obvious only when certain clinical extremes are considered. The patients who died while under observation were, with few exceptions, those who showed striking mental abnormalities, such as delirium, coma or stupor; and it is just these whose serum calcium concentrations are nearest to calculated values. The exceptions are three (cases 8, 21 and 46). It is worthy of note that the first of these exceptions (case 8), with abnormally high calcium, showed the rather unusual type of delirium for pellagra was overactive, requiring restraint. He was a drunkard, but his psychosis was not clearly either an hallucinosis or delirium tremens. The second (case 21) suffered formore than a month from severe peripheral neuritis, showed ankle clonus, but was mentally clear and quick at the time of our study. Shortly after, she developed hyperpyrexia without known cause, became delirious, talked continuously and died. Ten others of the 16 pellagrins (cases 2, 11, 13, 16, 17, 22, 31, 36, 40 and 47) who died showed psychoses characterized by hypo- rather than 
hyperactivity, mental and physical, varying from drowsiness, with periods of confusion and disorientation, to coma. None of these ten showed a serum calcium content which varied from the calculated value by more than 11 per cent and the average deviation from the calculated values is +2 per cent. Another pellagrin (case 37), though without psychosis, showed such apathy and mental retardation that a clinical diagnosis of hypothroidism was made. Of two determinations of basal metabolic rate one was low and the other normal. Contrasting clinically with these hypoactive pellagrins, the most extreme examples of which are the ten patients just mentioned, were individuals who without psychosis tended to be overative physically and mentally, who were out of bed on every possible occasion, were quick to answer questions, frequently were witty and were considered the life of the ward. Six patients (cases 1, 21, 25, 27, 32, 34) were of this type. They all showed, as compared with calculated values, high serum calcium content, the average deviation from calculated values being +24 per cent. Each of these six patients also showed another clinical feature - evidence of peripheral neuritis and also of cord damage. They complained of severe pains in the legs and less severe pains in the hands for long periods. The calf muscles were tender and there were areas of impaired sensation for pain over the tibia, while the deep reflexes were greatly exaggerated. One patient (case 21) showed an ankle clonus. No patients other than these showed clear evidence of neuritis, though it may have been overlooked in some of the psychotic patients. Two of these patients (cases 1 and 34) had been heavy drinkers of alcohol, one (case 34) recently enough for it to have played an important part in the pathogenesis of the neuritis. The peculiar neuritis seen in pellagra is believed, by some observers, to be due to arsenic or to complicating beriberi. The patients here referred to were scarcely improved by a diet containing an abundance of antineuritic vitamin, and they gave no history of taking arsenicals.

Between these two extremes clinically and chemically fall the majority of our pellagrins.

As to the stage of the disease represented by the high and normal calcium groups there seems to be little difference. The normal calcium group contains a greater number of early cases than the other. Final interpretation of our observations on serum calcium must await further. 
study, directed particularly to determinations of calcium intake and output. From serum calcium determinations alone it is impossible to say whether high levels for calcium mean positive or negative calcium balance. In a general way the findings may be said to indicate that there is in pellagra some influence which tends to give elevated serum calcium levels, and that in the very severe cases there is another influence which tends to bring serum calcium back to normal levels. The first factor might be either excess of vitamin $D$, which tends to promote increased absorption and deposition of calcium in the tissues, or a factor like hyperparathyroidism, which causes excessive excretion of calcium. Differences in hydrogen ion concentration apparently are not responsible for differences in serum calcium concentration since the $\mathrm{CO}_{2}$ combining power in nearly all instances was within normal range, and in those in which it was abnormal there was no definite peculiarity in regard to serum calcium concentration.

The possibility that albumin and globulin might differ in their effect on the solubility of calcium was entertained. The formula of Peters and Eiserson assumes that they have equal value. Instances were found in the data which seemed to indicate such a difference, but they were too few to carry much weight.

At first glance one suspects that the reason serum calcium levels are lower in severe pellagra than in milder forms of the disease, is that fixed base, of which calcium is one constituent, is low. This idea receives some support from studies of correlation. It was found that slight correlation $^{1}$ existed between per cent deviation of calcium from calculated value and per cent deviation of total base from $155 \mathrm{~m} . \mathrm{Eq}$. per liter.

The diet taken by our pellagrins while under observation was fairly rich in vitamin D. Ninety cubic centimeters daily of fresh unirradiated brewer's yeast and 100 grams of liver were the chief sources of vitamin D. A few patients received small doses of cod liver oil, but serum calcium was not apparently affected in those cases.

Havard and Hoyle (12) found that doses of irradiated ergosterol which were active therapeutically for rickets, were without effect on the serum calcium and phosphorus of an healthy adult; while Kam-

$$
{ }^{\prime} r=+0.398 \pm 0.08 \text {. }
$$


insky and Davidson (13) noted marked rises in serum calcium in tuberculous adults with similar dosage. It is very likely that various states of health may cause individuals to react differently to vitamin $\mathrm{D}$ therapy. It is of some interest that the highest serum calcium level for one patient (case 34) followed prolonged daily exposure, while dressed, to the rays from the summer sky. Only one other patient (case 1) was exposed to more light than the diffuse light of the ward. During the latter one-half of the time he was under study he exposed himself dressed in pajamas to the radiation from the sky for from one to three hours daily.

It is possible that the failure of calcium to reach the higher levels in the severe cases, is due to a severely damaged intestinal mucosa which interferes with absorption. Studies on healthy individuals indicate that serum calcium levels seem to be above the calculated normal more frequently than below it. Another factor which may be of importance is the reaction of the intestinal contents, which is known to have an influence on the absorption of calcium and phosphorus. The frequent achlorhydria of pellagra suggests that there is in many cases a change in reaction of the intestinal contents in the direction of alkalinity. The few patients in our series whose gastric contents contained free hydrochloric acid were not uniformly different from those showing achlorhydria.

Diarrhea was more usually associated with the lower serum calcium concentrations and may have interferred mechanically with calcium absorption. If intestinal damage were the chief factor in regulating serum calcium levels for pellagrins on complete diet, the relationship between nervous symptoms and serum calcium might prove to be incidental and of minor importance.

\section{SUMMARY}

One hundred and eighty-one simultaneous determinations of serum calcium, inorganic phosphorus, albumin, and globulin are reported in a study of 48 pellagrins: 7 patients with pellagra-like conditions, 24 ward patients with heterogeneous disorders and 3 patients with bone disease.

Observed values for serum calcium were compared with the calculated values based on concentration of inorganic phosphorus and serum 
protein (albumin plus globulin) using the formula of Peters and Eiserson. Per cent deviation from calculated values for each determination is indicated graphically.

As a group, the pellagrins showed a tendency for observed values to be higher than the calculated figures, whereas the patients without pellagra showed little difference between calculated and determined values.

The pellagrins with little deviation of the observed values for serum calcium from the calculated values, were characterized clinically by psychoses and fatal terminations. The psychoses of this group were marked by hypoactivity, mental and physical.

Six pellagrins had determined serum calcium concentrations markedly greater than the calculated values and were characterized clinically by tendency to mental and physical overactivity, conspicuous clearness of mind and also by evidences of neuritis. One patient with high serum calcium presented wild delirium.

The majority of the patients with pellagra were grouped on clinical grounds and according to their serum calcium levels in an intermediate position between the extremes mentioned above.

Calculation of correlation coefficient indicates that serum calcium levels are slightly correlated with concentrations of total fixed base.

\section{CONCLUSIONS}

Sufficient evidence of disturbed serum calcium concentration is presented to justify further study.

Abnormalities of serum calcium concentration in pellagrins seem to be related to disturbances of the nervous system. Whether the relationship is causal or incidental is unknown.

\section{BIBLIOGRAPHY}

1. Siler, J. F., Garrison, P. E., and MacNeal, W. J., Arch. Int. Med., 1916, xviii, 173. The Incidence of Pellagra in Spartanburg County, S. C., and the Relation of the Initial Attack to Race, Sex and Age.

2. Siler, J. F., Garrison, P. E., and MacNeal, W. J., Arch. Int. Med., 1917, xix, 404. The Relation of Pregnancy and Childbirth to Pellagra in Women.

3. Maxwell, J. P., China Med., J., 1923, xxxvii, 625. Osteomalacia in China. Maxwell, J. P., and Miles, L. M., J., Obst. and Gynec. Brit. Emp., 1925, $\mathrm{xxxii}, 433$. Osteomalacia in China.

Wampler, F. J., China Med., J., 1924, xxxviii, 349. Osteomalacia in China. 
4. Denton, J., Am. J. Trop. Med., 1925, v, 173. The Pathology of Pellagra.

5. Kreitmair, H., and Moll, T., Münch. Med. Wchnschr., 1928, Ixxv, 637. Hypervitaminose durch grosse Dosen Vitamin D.

Harris, L. J., and Moore, Thomas, Biochem. J., 1929, xxiii, 261. XXXV. Hypervitaminosis and Vitamin Balance. Part II. The Specificity of Vitamin D in Irradiated Ergosterol Poisoning. Part III. The Pathology of Hypervitaminosis D.

Shohl, Alfred T., Goldblatt, Harry, and Brown, Helen B., J. Clin. Invest., 1930, viii, 505. The Pathological Effects Upon Rats of Excess Irradiated Ergosterol.

6. Ballif, L., and Gherscovici, I., Compt. rend. Soc. de Biol., 1928, xcviii, 393. - La Réserve alcaline et la Calcémie dans la Pellagre

7. Clark, E. P., and Collip, J. B., J. Biol. Chem., 1925, lxiii, 461. A Study of the Tisdall Method for the Determination of Blood Serum Calcium with a Suggested Modification.

8. Gunther, L., and Greenberg, D. M., J. Biol. Chem., 1929, lxxxii, 551. A Note on the Determination of the Inorganic Phosphate of the Serum on the Filtrate from Calcium Analysis.

9. Turner, R. H., J. Clin. Invest., 1931, x, 71. The Pathologic Physiology of Pellagra. II. The Serum Albumin and Globulin.

10. Turner, R. H., J. Clin. Invest., 1931, x, 61. The Pathologic Physiology of Pellagra. I. Tabulated Clinical and Physiologic Data.

11. Peters, John P., and Eiserson, Leo., J. Biol. Chem., 1929, lxxxiv, 155. The Influence of Protein and Inorganic Phosphorus on Serum Calcium.

12. Havard, E. R., and Hoyle, J. C., Biochem. J., 1928, xxii, 713. Vitamin D in Adults. Its Effect on the Calcium and Inorganic Phosphate of the Blood.

13. Kaminsky, Jacob, and Davidson, Doris L., Am. Rev. Tuberc., 1930, xxii, 48. A Note on the Effect of the Oral Administration of Irradiated Ergosterol on the Calcium Concentration of the Blood Serum in Pulmonary Tuberculosis. 